\title{
„Pejzaż górski nie odpowiadał mi malarsko"1. Zakopiański epizod graficzny Jana Skotnickiego
}

DOI: https://doi.org/10.21697/an.9374

URSZULA DRAGOŃSKA

UNIWERSYTET WARSZAWSKI, GABINET RYCIN BUW

ORCID 0000-0002-1323-5031

Jan Skotnicki (1876-1968) - nieco zapomniany młodopolski malarz, a w okresie dwudziestolecia międzywojennego głównie działacz polityczny - zainteresował się sztukami graficznymi na krótko przed wybuchem I wojny światowej. Ten artystyczny epizod zakiełkował i rozwinął się w artystyczno-intelektualnym środowisku Zakopanego. O wpływie atmosfery stolicy polskich gór na życie artystyczne i o zjawisku Młodej Polski tatrzańskiej napisano już wiele. Tym bardziej warto przyjrzeć się twórczości, która zrodziła się niejako z tendencji odmiennej - braku fascynacji górskim krajobrazem i tutejszą sztuką ludową, poczucia zagubienia i osamotnienia w trakcie koniecznego pobytu w kurorcie i poszukiwania nowej drogi twórczej. Drogi, która okazała się istotnym elementem odrodzenia sztuk graficznych na ziemiach polskich w pierwszych dekadach XX w.

1 Jan Skotnicki, Przy sztalugach i przy biurku, Warszawa 1957, s. 135. Rękopis wspomnień znajduje się w Wojewódzkiej Bibliotece Publicznej w Łodzi (Rps XIV/1-2), a maszynopis w Bibliotece Narodowej (BN: Rps 6395-6396 IV).
Małżeństwo Skotnickich przyjechało do Zakopanego w $1908 \mathrm{r}$. z powodu złego stanu zdrowia żony artysty. Teodora z Trenklerów (1881-1963) była pasierbicą łódzkiego przemysłowca, kolekcjonera i mecenasa, Henryka Grohmana (1862-1939), właściciela zakopiańskiej willi Zofiówka, w której Skotniccy przebywali z niewielkimi przerwami do $1917 \mathrm{r}^{2}$ Skotnicki nie

2 Biografia J. Skotnickiego za: S. Konarski, Skotnicki Jan, w: Polski słownik biograficzny, t. 38, Warszawa 1997-1998, s. 302-305. Najnowsza nota o artyście: C. Rohrschneider, Skotnicki Jan, w: Allgemeines Künstlerlexikon. Die Bildenden Künstler aller Zeiten und Völker, Bd. 104, Berlin-Boston 2019, s. 201-202. Ślub Jana z Teodorą, jedną z trzech córek Matyldy Grohman (1859-1939) z pierwszego małżeństwa, odbył się w 1905 r. w Paryżu. Zofiówka - willa w stylu zakopiańskim, powstała pod koniec XIX w. według projektu Stanisława Witkiewicza. Należała pierwotnie do Stanisława Sas Dolińskiego (1894?-1942), od którego odkupił ją Grohman (A.D. Sznapik, Tatrzańska Arkadia. Zakopane jako ośrodek artystyczno-intelektualny od około 1880 do 1914 roku, Warszawa 2009, s. 160, il. 86). Po jego śmierci, w 1939 r., siostry Trenkler podarowały willę Kasie Mianowskiego z przeznaczeniem na pracownię i dom wypoczynkowy dla naukowców i artystów. Posiadłość spłonęła 18 IV 1946 r. (J. Woźniakowski, Dobrańsze niż indziej towarzystwo. Życie artystyczne w Zakopanem do roku 1939, w: Zakopane. Czterysta lat dziejów, red. R. Dutkowa, t. 2, Kraków 1991, s. 227). Siostra Teodory, Elżbieta Trenkler (1882-1977) wspomina, że Skotniccy mieszkali nie w Zofiówce, a w sąsiedniej willi - Leontynówce (E. Trenklerówna, Ze wspomnień o Mieczysławie Karłowiczu, „Ruch Muzyczny”, 1968, nr 8, s. 5). 
podszedł do zmiany miejsca zamieszkania z entuzjazmem. Przeciwnie, żałował zerwania z Krakowem, którego atmosfera i środowisko stanowiły dlań twórczą pożywkę3. W momencie przyjazdu do stolicy Tatr był artystą młodym, ale już ukształtowanym. Uprawiał malarstwo olejne o tematyce pejzażowej i rodzajowej oraz rysunek. Portretował przedstawicieli krakowskiej cyganerii artystycznej i twórców z kręgu kabaretu Zielony Balonik4. Paradoksalnie Zakopane, które dla tak wielu twórców stanowiło miejsce inspiracji, na Skotnickiego podziałało zgoła odmiennies. Nie odpowiadał mu tutejszy krajobraz „zbyt pompatyczny, pozbawiony wdzięku", jak uważał. Nie fascynowała góralska mentalność i sztuka ludowa. „Przy tym wszystko to było zanadto obmalowane, obfotografowane, obreklamowane", wspominał ${ }^{6}$. Malarz nie odnalazł się również w tutejszym

3 J. Skotnicki, Przy sztalugach..., dz. cyt., s. 135.

4 Ukończył warszawską Klasę Rysunkową Adama Badowskiego, studiował na ASP w Petersburgu (1898-1899, 1903-1904) i w Krakowie (1900-1903) pod kierunkiem Jacka Malczewskiego, Józefa Mehoffera i Teodora Axentowicza oraz malarstwo w Académie Colarossi w Paryżu (1904). Wystawiał w Towarzystwie Przyjaciół Sztuk Pięknych (dalej jako TPSP) w Krakowie (1904) i we Lwowie (1906) oraz Towarzystwie Zachęty Sztuk Pięknych (dalej jako TZSP) w Warszawie (1906, 1907, 1908/9. S. Konarski, dz. cyt., s. 302). Rysunki artysty przechowuje Biblioteka Narodowa (dalej jako BN. M. Grońska, Rysunki artystów polskich i obcych w Polsce działajacych od XVII do XX wieku. Katalog wybranych zbiorów Biblioteki Narodowej do 1975 roku, Warszawa 1991, s. 160-168, poz. 1756-1843) oraz Muzeum im. Jerzego Dunin-Borkowskiego w Krośniewicach (dalej jako MK. Por. Jan Skotnicki - malarz i jego warsztat, katalog wystawy], MK, lipiec-wrzesień 1998, oprac. i tekst P. Stasiak, Krośniewice 1998). Część zreprodukowano w tomie wspomnień artysty.

5 Kulturalną panoramę miasta tego czasu prezentują: K. Estreicher, Środowisko artystyczne Zakopanego w okresie Młodej Polski (1900-1914), w: Sztuka około 1900. Materiały sesji Stowarzyszenia Historyków Sztuki, Kraków, grudzień 1967, Warszawa 1969, s. 129-140; J. Woźniakowski, Dobrańsze niż..., dz. cyt., s. 189-235; A.D. Sznapik, dz. cyt.; T. Jabłońska, Sztuki piękne pod Tatrami, Zakopane 2015.

6 J. Skotnicki, Przy sztalugach..., dz. cyt., s. 135. środowisku artystyczno-intelektualnym. Poczucie odosobnienia pogłębiła tragiczna śmierć bliskiego Skotnickim, Trenklerom i Grohmanon Mieczysława Karłowicza, który zginął pod lawiną w 1909 r.7

Jacek Woźniakowski, analizując rozwój kulturalny Zakopanego, uznał lata 1909-1910 za przełomowe. To właśnie w tym czasie, w sprzyjającej atmosferze kurortu skupiającego przedstawicieli świata sztuki i intelektualistów ze wszystkich zaborów, przy względnej swobodzie politycznej, którą cieszyła się Galicja, wydarzenia artystyczne zaczęły nabierać rozpędu. Przy okazji większości z tych inicjatyw natrafiamy na nazwisko Skotnickiego. W 1909 r. wspólnie z Kazimierzem Brzozowskim, Janem Dworskim i Władysławem Skoczylasem założył Towarzystwo „Sztuka Podhalańska"9. Rok później Brzozowski, Skotnicki i Bohdan Treter zainicjowali powstanie Spółdzielni „Kilim”. W pierwszych latach jej działalności Skotnicki pełnił funkcję kierownika artystycznego i wspólnie z żoną wykonywał projekty tkanin ${ }^{10}$. W styczniu 1909 r. małżeństwo Skotnickich wzięło udział w pierwszej wystawie artystów zakopiańskich zorganizowanej w gmachu

7 Szczególne relacje łączyły go zwłaszcza z Elżbietą Trenkler, uznawaną za jego „nieoficjalną narzeczoną”. Ze Skotnickim znali się od czasów szkolnych. Elżbieta, Teodora i Jan spędzili z kompozytorem jego ostatni wieczór przed śmiercią. Tragedia znalazła odbicie we wspomnieniach Skotnickiego i w jego twórczości: Śmierć Karłowicza, 1909, olej na tekturze, Muzeum Narodowe w Poznaniu (dalej jako MNP, Mp 1531); Znalezienie zwłok Karłowicza, 1909, kredki, ołówek, (BN, nr inw. R.950). J. Skotnicki, dz. cyt., s. 137-138; Mieczysław Karłowicz w listach i wspomnieniach, oprac. H. Anders, Kraków 1960, s. 586-610; A. Wightman, Karłowicz, Młoda Polska i muzyczny fin de siècle, Kraków 1996, s. 113-115.

8 J. Woźniakowski, Dobrańsze niż..., dz. cyt., s. 202-206; A.D. Sznapik, dz. cyt., s. 44.

9 J. Woźniakowski, O wystawach „Sztuki Podhalańskiej”, „Roczniki Humanistyczne”, t. 34, 1986, z. 2, s. 525-530.

10 I. Huml, Stowarzyszenie Kilim, w: Polskie życie artystyczne w latach 1890-1914, red. A. Wojciechowski, Wrocław-Warszawa-Kraków 1967, s. 195-196. 
Biblioteki Publicznej. Wystawiali obok takich artystów jak Teodor Axentowicz, Julian Fałat), Jan Rembowski, Władysław Skoczylas czy Leon Wyczółkowski. Z kolei w kwietniu uczestniczyli w konkursie na projekt zabawki rozpisanym przez „Sztukę Podhalańską". Choć ostatecznie nie przyznano pierwszej nagrody, to propozycje Skotnickich spotkały się z dużym uznaniem. W grudniu zaprezentowali swoje prace na wystawie pejzażu urządzonej przez Towarzystwo w willi Jutrzenka. W 1910 r. Skotnicki otrzymał pierwszą nagrodę za projekt kilimu. Ponadto $\mathrm{z}$ jego ramienia wziął udział w dwóch wystawach we Lwowie: Powszechnej Wystawie Sztuki Polskiej w 1910 r. i Wystawie Podhalańskiej w roku następnym ${ }^{11}$. Warto nadmienić, że inicjatywy „Sztuki Podhalańskiej” i „Kilimu” nie obyłyby się bez wsparcia finansowego Grohmana ${ }^{12}$.

Na krótko po przyjeździe Skotnicki zainteresował się sztukami graficznymi: „Roślinność górska, te miliony jednakowych smreków jakby sztancą na jedną modłę wykonanych, latem czy zimą takim samym kolorem pomalowanych, doprowadzały mnie do rozpaczy. Nic też dziwnego, że przy takim ustosunkowaniu się moim do otoczenia o poważniejszej pracy malarskiej nie mogło być mowy. Wolałem kilimiarstwo i grafikę. Teść mój, Henryk Grohman, widząc tę moją niechęć do Zakopanego, a sam będąc w nim rozmiłowany, chciał mi ulżyć. W tym celu

11 J. Woźniakowski, O wystawach..., dz. cyt., s. 526.

12 Dowodem wdzięczności artystów jest rycina autorstwa Skoczylasa, z dedykacją dla mecenasa, którą bezpośrednio na matrycy podpisali członkowie „Sztuki Podhalańskiej”: Profil górala, 1914, akwaforta, Gabinet Rycin Biblioteki Uniwersyteckiej w Warszawie (dalej jako GR BUW, Inw.Dep. 4724 - odbitka, Inw.Dep. 4933 - matryca). O mecenacie Grohmana: W.M. Rudzińska, Henryk Grohman - mecenas i kolekcjoner, w: Mecenas, kolekcjoner, odbiorca. Materiały Sesji Stowarzyszenia Historyków Sztuki, Katowice, listopad 1981, red. E. Karwowska, A. Marczak-Krupa, Warszawa 1984, s. 179-195. zainicjował utworzenie ośrodka artystycznego z pracownią eksperymentalną kilimiarsko-gobelinową, batikową, ceramiczną oraz graficzną. Zaczęły więc z całego niemal świata napływać do Zakopanego warsztaty tkackie, wełny, jedwabie, woski, różne tkaniny, prasy graficzne, narzędzia rylce itd." ${ }^{13}$ Powstał w ten sposób odrębny ośrodek graficzny, wymieniany przez Irenę Kossowską obok tych najważniejszych: krakowskiego i warszawskiego ${ }^{14}$. Według Skotnickiego właśnie w zakopiańskiej pracowni pierwsze kroki graficzne miał stawiać Skoczylas ${ }^{15}$. Jednak autorka jego najnowszej monografii, Maryla Sitkowska, nie podejmuje tego wątku. Najwcześniejsze akwaforty i suche igły, datowane na 1910 r., wiąże z pobytem artysty w Paryżu i nauką w pracowni Jana Rubczaka ${ }^{16}$. O tym, że Skoczylas mógł korzystać z zakopiańskiej pracowni graficznej po powrocie ze stolicy Francji, wspomina natomiast Maria Grońska ${ }^{17}$. Warto jednak zauważyć, że pierwsze znane prace graficzne Skoczylasa stoją na bardzo wysokim poziomie artystycznym i technicznym. Musiały je poprzedzać niezachowane wprawki, które być może powstawały właśnie w zakopiańskiej pracowni.

\footnotetext{
13 J. Skotnicki, Przy sztalugach..., dz. cyt., s. 139. Należałoby się zastanowić, czy faktycznie jedynym impulsem do podjęcia wspomnianych inicjatyw była dla Grohmana troska o zięcia i czy nie przeważyły tu zainteresowania własne i podsycanie pasji artystycznych sióstr Trenkler, nad którymi sprawował pieczę.

14 I. Kossowska, Narodziny polskiej grafiki artystycznej 1897-1914, Kraków 2000, s. 61. Krystyna Czarnocka określa go mianem filii środowiska krakowskiego, zaznaczając, że większość działających tu twórców wywodziła się z Akademii Sztuk Pięknych w Krakowie i była związana z Towarzystwem „Polska Sztuka Stosowana”. K. Czarnocka, Półtora wieku grafiki polskiej, Warszawa 1962, s. 241.

15 J. Skotnicki, Przy sztalugach..., dz. cyt., s. 139.

16 M. Sitkowska, Władysław Skoczylas (1883-1934), Warszawa 2015, s. 27-28.

17 M. Grońska, Władysław Skoczylas, Wrocław 1966, s. 9.
} 
Wydarzeniem najważniejszym dla zakopiańskich rytowników był pierwszy, ogólnopolski konkurs graficzny ogłoszony w 1911 r. przez krakowskie TPSP, nazwany imieniem Grohmana dla zaznaczenia jego wkładu w odrodzenie tej sztuki. Na wystawie pokonkursowej inaugurującej otwarcie Bazaru Polskiego przy Krupówkach ${ }^{18}$ pokazano prace m.in. Gustawa Gwozdeckiego, Feliksa Jabłczyńskiego, Karola Mondrala, Jana Rubczaka, Zofii Stankiewiczówny i Władysława Skoczylasa, który uzyskał pierwszą nagrodę. Skotnicki wraz ze swoim teściem oraz Teodorem Axentowiczem, Piotrem Stachiewiczem i Feliksem Koperą zasiadł w jury. Był też jedynym artystą wystawiającym poza konkursem ${ }^{19}$. W recenzji podsumowującej wydarzenie podkreślił znaczenie linii w sztukach graficznych oraz umiejętne wyzyskanie przez artystów cech przynależnych poszczególnym technikom ${ }^{20}$. Konkurs, łącząc artystów reprezentujących różne środowiska (Paryż, Warszawa, Kraków, Zakopane), był niezwykle ważny dla rozwoju rodzimych sztuk graficznych i umożliwił przepływ wzajemnych inspiracji artystycznych ${ }^{21}$. Jak jednak zauważyła Adrianna Dominika Sznapik, „w omawianym okresie Zakopane nie było mimo wszystko renomowanym miejscem wystawowym dla artystów malarzy"22.

18 Z. Moździerz, O powstaniu „Bazaru Polskiego” w Zakopanem, w: W stulecie Bazaru Polskiego - Henryk Grohman i grafika Młodej Polski [katalog wystawy, Miejska Galeria Sztuki im. Władysława hr. Zamoyskiego w Zakopanem], Kraków 2011, s. 4-11.

19 W.M. Rudzińska, Wystawa graficzna w Bazarze Polskim w Zakopanem i Henryk Grohman - przemysłowiec, mecenas sztuki, kolekcjoner, w: W stulecie Bazaru..., dz. cyt., s. 36-42.

20 J. Skotnicki, Kronika. Wystawa graficzna w Zakopanem, „Sztuka. Miesięcznik ilustrowany poświęcony sztuce i kulturze", 1911, z. 1, s. 144-147.

21 I. Kossowska, Świat odrealniony. Polska grafika artystyczna (1897-1917), w: W stulecie Bazaru..., dz. cyt., s. 34.

22 A.D. Sznapik, dz. cyt., s. 97. Stwierdzenie to dotyczy tak samo artystów grafików.
Podejmowane tu inicjatywy miały charakter charytatywny i stanowiły rodzaj kulturalnej rozrywki dla kuracjuszy i letników. Dostrzegał to sam Stanisław Witkiewicz, pisząc do syna: „Co do wystawy [...] w Zakopanem nie warto. Koszta i trudy, a pożytek żaden" i polecał Kraków, Lwów i Warszawę ${ }^{23}$. Rozumiał to także Skotnicki, od początku prezentując ryciny poza tatrzańskim kurortem, co tylko potwierdza, że traktował tę dziedzinę sztuki poważnie. Po raz pierwszy eksponował je publicznie w Krakowie w 1909 r. ${ }^{24}$ oraz na VI Salonie TZSP w Warszawie na przełomie 1909 i 1910 r. ${ }^{25}$ Większy wybór akwafort zaprezentował na III wystawie Grupy Artystów Polskich „Odłam” w Warszawie w 1910 r. ${ }^{26}$ Ważna była również lwowska ekspozycja „Sztuki Podhalańskiej" z 1911 r., na której akwaforty artysty dekorowały wnętrze zaprojektowane przez Skoczylasa w stylu zakopiańskim ${ }^{27}$. Uwagę krytyków zwracała przede wszystkim sprawność techniczna Skotnickiego ${ }^{28}$.

23 List z 16 VIII 1911 r. Cyt. za: tamże, s. 97.

24 Nie udało się ustalić, o jaką wystawę chodziło. Pamiątka z wystawy graficznej i konkursu II-go imienia Henryka Grohmana [katalog wystawy, luty 1914], Warszawa 1914, s. 36

25 J. Wiercińska, Katalog prac wystawionych w Towarzystwie Zachęty Sztuk Pięknych w Warszawie w latach 1860-1914, Wrocław-Warszawa-Kraków 1969, s. 338. Wymienione tytuły (Akwaforta kolorowa I, Akwaforta kolorowa II i Główka) nie pozwalają połączyć tych prac z żadnymi współcześnie znanymi.

26 III wystawa Grupy Artystów Polskich „Odłam” [katalog wystawy, kwiecień-maj 1910], Warszawa 1910, s. 17-18. Wprawdzie katalog nie zawiera informacji o technice wykonania prac, jednak ich tytuły są tożsame ze znanymi akwafortami (Rzepicha,Jodła, Kareta, Słoneczniki, Wejście do kościoła, Na fotelu). Na obecność prac graficznych Skotnickiego zwrócili również uwagę recenzenci: Dział grafiki na wystawie Odłamu w TZSP, „Kurier Warszawski”, 1910, nr 143 (wydanie wieczorne), s. 6; J. Kleczyński, Z wystawy „Odłamu”. Szkice sylwetek, „Sfinks. Czasopismo literacko-artystyczne i naukowe”, r. 3, 1910, nr 10, s. 313.

27 Katalog wystawy podhalańskiej [katalog wystawy], Lwów 1911, s. 31.

28 M. Dienstl, Warszawskie Tow. artystów grafików, „Świat”, 1913, nr 17, s. 11; W. Wankie, Nasza grafika współczesna, „Świat”, 1914, nr 5, s. 6. 
Jest to tym bardziej warte podkreślenia, że artysta bardzo szybko opanował warsztat technik metalowych. Henryk Piątkowski uważał wręcz, że „w gronie polskich malarzy, którzy przystosowali do swoich potrzeb technikę akwafortową, Skotnicki w krótkim czasie zajął jedno z wydatniejszych miejsc i stanął obok Stankiewiczówny i Pankiewicza" 29.

W 1912 r. Skotnicki opuścił Zakopane i przeniósł się do Warszawy, gdzie jego zainteresowanie grafiką dalej się rozwijało ${ }^{30}$. Przyłączył się do powstałego z inicjatywy Ignacego Łopieńskiego, Hieronima Wildera i Franciszka Ejsmonda Towarzystwa Przyjaciół Sztuk Graficznych (TPSG). Rok później wziął udział w wystawie Towarzystwa, na której zaprezentował głównie swój zakopiański dorobek. Wygłosił także cykl 12 popularyzatorskich wykładów O różnicach technik graficznych ${ }^{31}$. W tym samym roku 41 prac artysty trafiło do 16. Katalogu Antykwariatu Wildera Nowoczesna grafika polska, które to wydawnictwo po raz pierwszy oficjalnie wprowadzało twórczość ówczesnych grafików na rynek sztuki ${ }^{32}$. W 1914 r. ryciny Skotnickiego pokazane zostały na wystawie towarzyszącej ogłoszonemu przez TPSG II konkursowi graficznemu im. Henryka Grohmana. I tym razem Skotnicki zasiadał w jury ${ }^{33}$. Należy

29 H. Piątkowski, Wystawa obrazów J. Skotnickiego, „Tygodnik Ilustrowany”, 1913, nr 45, s. 886.

30 J. Skotnicki, Przy sztalugach..., dz. cyt., s. 139. Teodora wraz z synem zostali w Zakopanem. Lata 1912-1914 spędzone w Warszawie nie znajdują żadnego odbicia we wspomnieniach Skotnickiego.

31 P.P. Czyż, Szkoła Łopieńskiego - Towarzystwo Przyjaciół Sztuk Graficznych, czyli warszawscy akwaforciści pierwszych dwóch dekad XX wieku, w: Wielość w jedności. Techniki wklęsłodruku w Polsce po 1900 roku. Materiały z sesji naukowej 18-19 października 2012 roku, red. B. Chojnacka, M.F. Woźniak, Bydgoszcz 2013, s. 73.

32 Nowoczesna grafika polska, Antykwariat Polski w Warszawie Hieronima Wildera i S-ki, Warszawa 1913, s. 16-17, poz. 363-403.

33 Pamiatka z wystawy..., s. 36, poz. 332-344. W.M. Rudziń- szczególnie podkreślić znaczenie podobnych inicjatyw, angażujących artystów i miłośników na rzecz odrodzenia sztuk graficznych, pozbawionych na ziemiach polskich historycznej ciągłości i kształtowanych niemal zupełnie na nowo ${ }^{34}$. Mimo powrotu w $1914 \mathrm{r}$. do swego graficznego matecznika, Skotnicki nie przejawił ponownego zainteresowania rytownictwem. Ten twórczy epizod zamyka wybuch I wojny światowej i przystąpienie artysty do Legionów Polskich 35 . Rodząca się po $1914 \mathrm{r}$. pod Tatrami awangarda spod znaku Stanisława Ignacego Witkiewicza czy braci Zbigniewa i Andrzeja Pronaszków, pozostawiła młodopolskiego na wskroś Skotnickiego na marginesie wydarzeń artystycznych ${ }^{36}$.

Podstawą analizy graficznego dorobku Skotnickiego jest największy zbiór jego prac przechowywany w Gabinecie Rycin Biblioteki Uniwersyteckiej w Warszawie, liczący 53 odbitki. Trzydzieści z nich pochodzi z kolekcji Grohmana przekazanej Uniwersytetowi w 1939 r. na mocy testamentu, którego jednym z wykonawców był sam Skotnicki ${ }^{37}$. Pozostałe prace artysta po-

ska, Nowoczesna grafika polska w świetle warszawskiej „Wystawy Graficznej” z 1914 r., w:Przed wielkim jutrem. Sztuka 1905-1918. Materiały Sesji Stowarzyszenia Historyków Sztuki, Warszawa, październik 1990, red. T. Hrankowska, Warszawa 1993, s. 325-339.

34 I. Kossowska, Poetyka czerni i bieli w sztuce polskiego modernizmu. Grafika i rysunek, w: Koniec wieku. Sztuka polskiego modernizmu 1890-1914 [katalog wystawy, Muzeum Narodowe w Warszawie, 15 listopada 1996 - 26 stycznia 1997, Muzeum Narodowe w Krakowie, 15 marca - 15 maja 1997], red. E. Charazińska, Ł. Kossowski, Warszawa 1996, s. 65-66.

35 Skotnicki zaangażował się także w działalność miejscowych organizacji patriotycznych. W okresie międzywojennym poświęcił się polityce. W latach 30. XX w. wrócił do malarstwa. S. Konarski, dz. cyt., s. 303.

36 T. Jabłońska, dz. cyt., s. 281-287.

37 O kolekcji zob. m.in.: W.M. Rudzińska, Henryk Grohman i jego kolekcja grafiki europejskiej i polskiej przełomu XIX i XX wieku, w: Polskie kolekcjonerstwo grafiki. Ludzie i instytucje, red. E. Frąckowiak, A. Grochala, Warszawa 2008, s. 128-137; D. Kacprzak, Kolekcje Ziemi Obiecanej. Zbiory artystyczne łódzkiej 
darował Bibliotece w 1957 r. Po II wojnie światowej twórczość Skotnickiego przypomniały dwie ekspozycje: jubileuszowa, zorganizowana w Centralnym Biurze Wystaw Artystycznych w 1957 r. oraz retrospektywna w Muzeum im. Jerzego DuninBorkowskiego w Krośniewicach w 1998 r. ${ }^{38}$ Do tej pory nie została ona poddana szczegółowej analizie. W kontekście odrodzenia sztuk graficznych w Polsce pisały o niej Wanda M. Rudzińska oraz Irena Kossowska, która poświęciła jej więcej uwagi ${ }^{39}$. Jego prace pojawiły się także na ważnych ekspozycjach dotyczących XX-wiecznych technik metalowych, sztuki polskiej przełomu wieków oraz kolekcji Henryka Grohmana ${ }^{40}$. Na podstawie dostępnych zbiorów, katalogów i opracowań liczba prac graficznych Skotnickiego została oszacowana na ponad 50 odrębnych kompozycji. W kolekcjach publicznych znajduje się obecnie przynajmniej 36 , niekiedy w kilku egzemplarzach ${ }^{41}$. Pozostałe to ryciny wymieniane w katalogach z epoki, które się nie zachowały, znajdują się w zbiorach prywatnych lub, z powodu stosowania różnych tytułów, nie są jednoznacznie łączone ze znanymi kompozycjami. Nie budzą one wątpliwości atrybucyjnych, jako

burżuazji wielkoprzemysłowej w latach 1880-1939, Warszawa 2015, s. 174-203.

38 Jubileuszowa wystawa prac Jana Skotnickiego [katalog wystawy, Centralne Biuro Wystaw Artystycznych, lipiec-sierpień 1957], Warszawa 1957; Jan Skotnicki - malarz..., dz. cyt., nlb.

39 M.in. W.M. Rudzińska, dz. cyt.; I. Kossowska, dz. cyt.

40 Wielość w jedności. Techniki wklęsłodruku w Polsce po 1900 [katalog wystawy, Muzeum Okręgowe im. Leona Wyczółkowskiego w Bydgoszczy, 23 września - 2 grudnia 2012], oprac. i red. B. Chojnacka, Bydgoszcz 2012; Koniec wieku..., dz. cyt.; Ze zbiorów Henryka Grohmana. Grafika i rzemiosło artystyczne [katalog wystawy, Muzeum Sztuki w Łodzi, 24 stycznia - 13 marca 1998], red. E. Fuchs, Łódź 1997.

41 Większość z nich znajduje się w GR BUW. Pozostałe w Bibliotece Jagiellońskiej (dalej jako BJ), Bibliotece Narodowej, Muzeum Mazowieckim w Płocku (dalej jako MMP), Muzeum Narodowym w Warszawie (dale jako MNW), Krakowie (dalej jako MNK) i Poznaniu. że Skotnicki sygnował większość z nich ołówkiem pod kompozycją lub bezpośrednio na matrycy inicjałem lub znakiem autorskim - dwie strzałki skierowane w górę i dół z herbu Skotnickich Bogoria. Kwestia datacji nie jest już tak jednoznaczna. Wszystkie prace w technikach metalowych powstały z pewnością w latach 1909-1914 ${ }^{42}$. Ponieważ odbitki w większości nie były datowane lub data została dopisana później, to pojawiają się tu pewne rozbieżności. Na postawie katalogów wystaw z epoki można natomiast stwierdzić, że większość prac artysta wykonał w Zakopanem do $1912 \mathrm{r}$.

Tematyka rycin Skotnickiego jest na wskroś młodopolska i podobnie jak w przypadku wielu ówczesnych peintre-graveurów mocno powiązana z malarską ${ }^{43}$. Odnajdujemy w nich nastrojowe pejzaże, fragmentaryczne ujęcia natury o wydźwięku panteistycznym, sentymentalne widoki miasteczek Lubelszczyzny, architektury Krakowa i Paryża, intymne akty, studia postaci z ludu, szkice zwierząt. Nic nie zdradza, że powstały one pod Tatrami - brak w nich elementów miejscowego krajobrazu i tak popularnej wówczas góralszczyzny. W dużej części nie były kompozycjami samodzielnymi. Skotnicki pracował w oparciu o własne obrazy z okresu krakowskiego i szkice rysunkowe. Za przykład mogą tu posłużyć akwaforty Lirnik i Głowa starca (il. 1), obie powtarzające centralną postać z kompozycji malarskiej Wielka pieśn przedstawiającej trzech muzyków w strojach ludowych ${ }^{44}$. W analogiczny sposób mogła po-

\footnotetext{
42 Ponadto znane są dwie litografie Skotnickiego: Wawel - fragment murów z Albumu artystycznego, 1903 (MNK III-ryc.-2207) oraz plakat do Wystawy graficznej w Zakopanem, 1911 (MNK III-af-631); a także ilustracja w cynkotypii do „Liberum Veto” z 1904 r., dla której dostarczył pierwowzór (MNK III-ryc.-46579/3).

43 I. Kossowska, Zmrok, w: Koniec wieku..., dz. cyt., s. 359.

44 GR BUW, Inw.G.R. 2872; Inw.G.R. 2842 Inw.Dep. 4763, Inw.Dep. 4935 (w przypisach przy pierwszej wzmiance w tekście o pracach Skotnickiego
} 


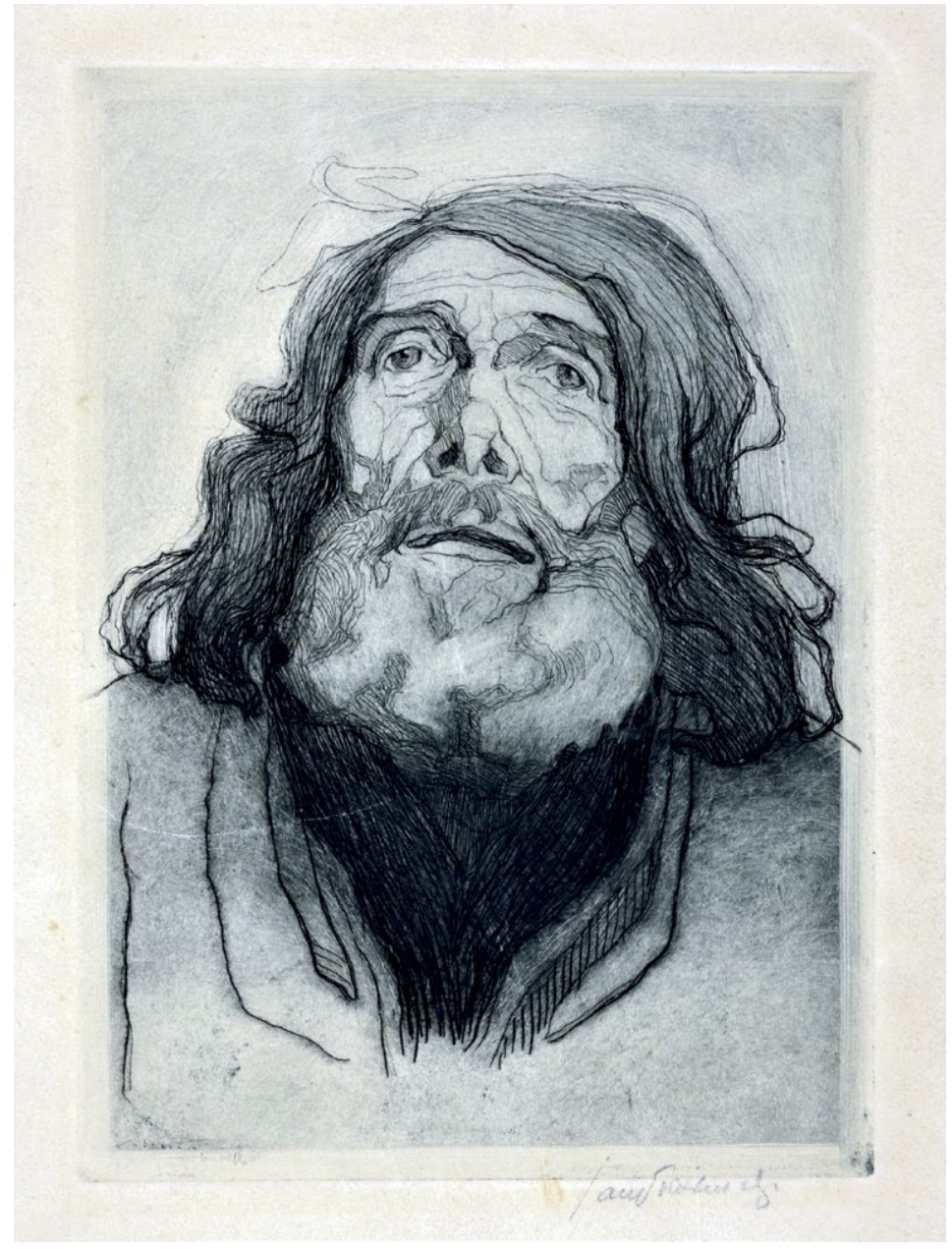

wstać rycina Rzepicha, oparta zapewne na znanym dziś jedynie z literatury płótnie Piast i Rzepicha, dla której istnieje także rysunek przygotowawczy ${ }^{45}$. Pierwowzory rysunkowe udało się ponadto ustalić dla kilku innych rycin, takich jak: Kościół w Rabce, Wejście do kościoła Saint Germain l'Auxerrois w Paryżu, Dworek, Dąb i Akt kobiecy z tyłu ${ }^{46}$.

z GR BUW podano wyłącznie numery inwentarzowe; dla prac spoza BUW lub innych autorów dane są bardziej szczegółowe). Nieznane jest obecnie miejsce przechowywania obrazu wystawionego w 1913 r. w TZSP w Warszawie i reprodukowanego w: „Tygodnik Ilustrowany”, 1913, nr 45, s. 885.

45 GR BUW, Inw.G.R. 2871, Inw.Dep. 4768, Inw.Dep. 4938. P. Stasiak, O malarstwie Jana Skotnickiego, w:Jan Skotnicki..., dz. cyt., nlb.; J. Skotnicki, Czepcowa z Bronowic, 1904, akwarela podrysowana ołówkiem i kredkami (BN, R.1667); M. Grońska, dz. cyt., s. 162, poz. 1773.

46 GR BUW, Inw.Dep. 4887, Inw.G.R. 2876, Inw.Dep. 4886, Inw.G.R. 2838, Inw.G.R. 2867, Inw.G.R. 2844, Inw.Dep. 4893. Są to kolejno: J. Skotnicki, Kościół w Rabce, 1912, ołówek, kredki (MNW, 123129 MNW);
1. Jan Skotnicki, Głowa starca, akwaforta, 1912 r., Gabinet Rycin Biblioteki Uniwersyteckiej w Warszawie. Fot. BUW

Kompozycja jest na nich podana w odbiciu lustrzanym w stosunku do rysunku. Skotnicki podjął także próbę w zakresie grafiki interpretacyjnej, biorąc za pierwowzór Bitwę po Grunwaldem Jana Matejki, z której w akwaforcie, tym razem przy zachowaniu właściwej strony, odtworzył Głowę Jungingena ${ }^{47}$.

W rycinach Skotnickiego wyraźne są, być może wzajemne, nawiązania tematyczne i kompozycyjne do malarskiej i graficznej twórczości młodopolskich artystów, z którą z pewnością był na bieżąco. Jego Burza, ukazująca dynamizm zjawiska atmosferycznego, bliska jest w wyrazie akwaforcie z suchą igłą Deszcz autorstwa Włodzimierza Kuglera z 1913 r., czy litografii Pogrzeb Leopolda Gottlieba z 1904 r., na której wiatr targa brzozami ponad głowami żałobników ${ }^{48}$. Z kolei Wisła pod Kazimierzem przywodzi na myśl wcześniejszą o 10 lat litografię Jana Stanisławskiego Wisła pod Tyńcem, w której również kompozycję wyznacza kręta linia brzegowa ograniczająca pustą przestrzeń rzecznej toni ${ }^{49}$. Słoneczniki (il. 2) bliskie są tym litografowanym przez Jana Wojnarskiego w 1909 r., zarówno w układzie kompozycyjnym z łodygami roślin na pierwszym planie, ale również w palecie i zbieżnym efekcie malarskim, uzyskanym mimo zastosowania odmiennych technik graficznych ${ }^{50}$.Źródeł inspiracji dla

tenże, Kościół St Germain l'Auxerrois w Paryżu, 1905, kredki, akwarela, złota farba (BN, R.1023, por. tamże, s. 163, poz. 1777); tenże, Widok ganku z drzewem, ołówek (MK, Dun.B./AH/8421/b); Studium drzewa, ołówek (MK, Dun.B./AH/8471/a); Akt kobiecy w pozycji stojącej tyłem, ołówek (MK, Dun.B./AH/8403/a), por. Jan Skotnicki - malarz..., dz. cyt., nlb.

47 GR BUW, Inw.Dep. 4766.

48 GR BUW, Inw.Dep. 4882); W. Kugler, Deszcz, 1913, akwaforta, sucha igła (MNW); L. Gottlieb, Pogrzeb, 1904, litografia (GR BUW Inw.G.R. 4349).

49 GR BUW, Inw.Dep. 4884; J. Stanisławski, Wisła pod Tyńcem, litografia, 1903, (GR BUW Inw.G.R. 1938/10).

50 GR BUW, Inw.G.R. 2838, Inw.Dep. 4883; J. Wojnarski, Słoneczniki, 1909, litografia barwna (MNW, 99782/8 


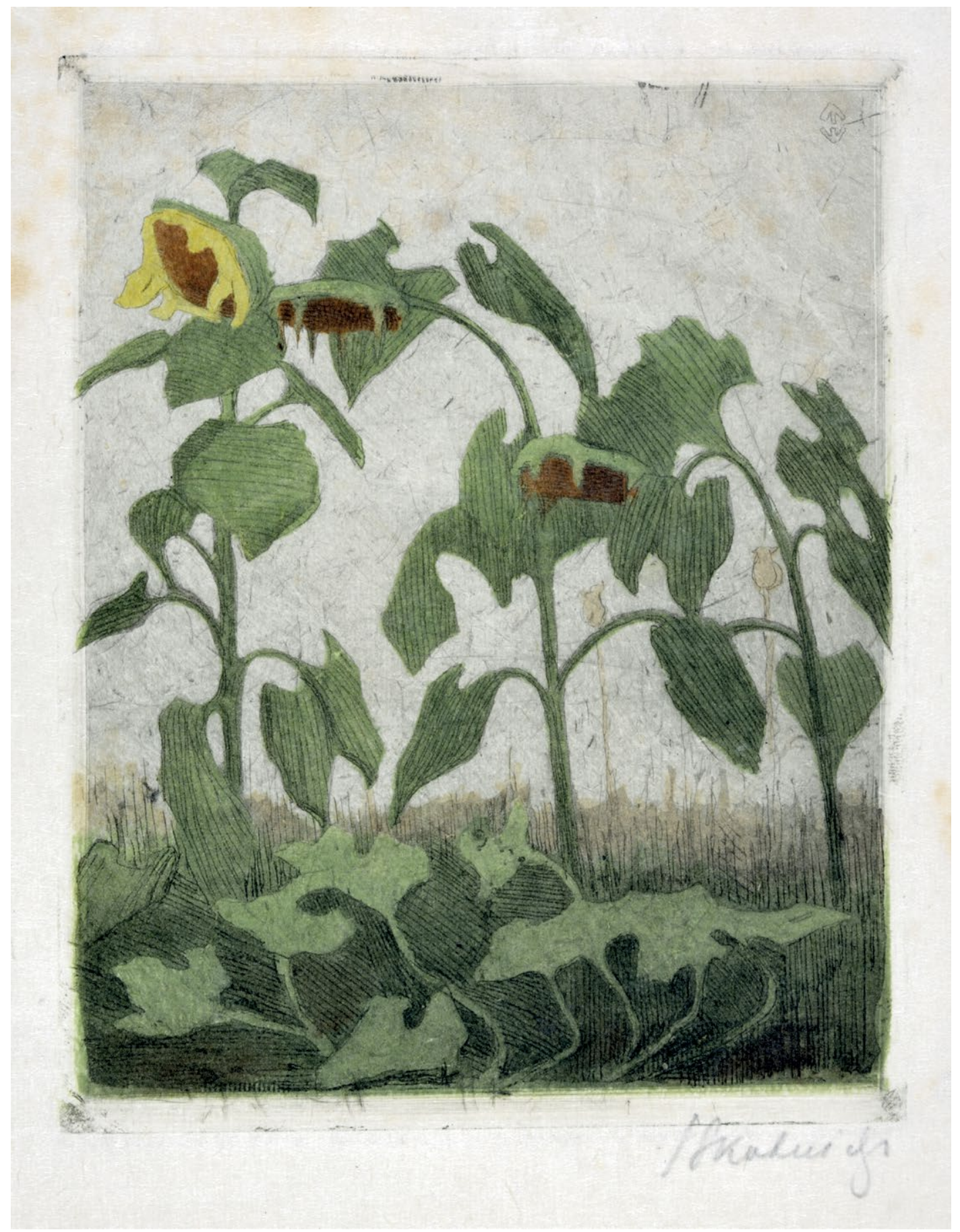

2. Jan Skotnicki, Słoneczniki, akwatinta, akwaforta barwna, 1911 r.,

Gabinet Rycin Biblioteki Uniwersyteckiej w Warszawie. Fot. BUW

obu artystów należałoby zapewne szukać w twórczości Stanisławskiego ${ }^{51}$. Nietrudno także znaleźć pewne tematyczne

MNW); tenże, Słoneczniki, 1911, litografia barwna, (MNK, MNK-III-ryc.-8903).

51 J. Stanisławski, Słoneczniki, 1903, olej na tekturze (MNK). i techniczne zależności z pracami zgłoszonymi w pierwszej, zakopiańskiej edycji konkursu graficznego im. Grohmana. Drewniany kościół w Rabce, choć w różnych ujęciach, pojawia się w pracach 


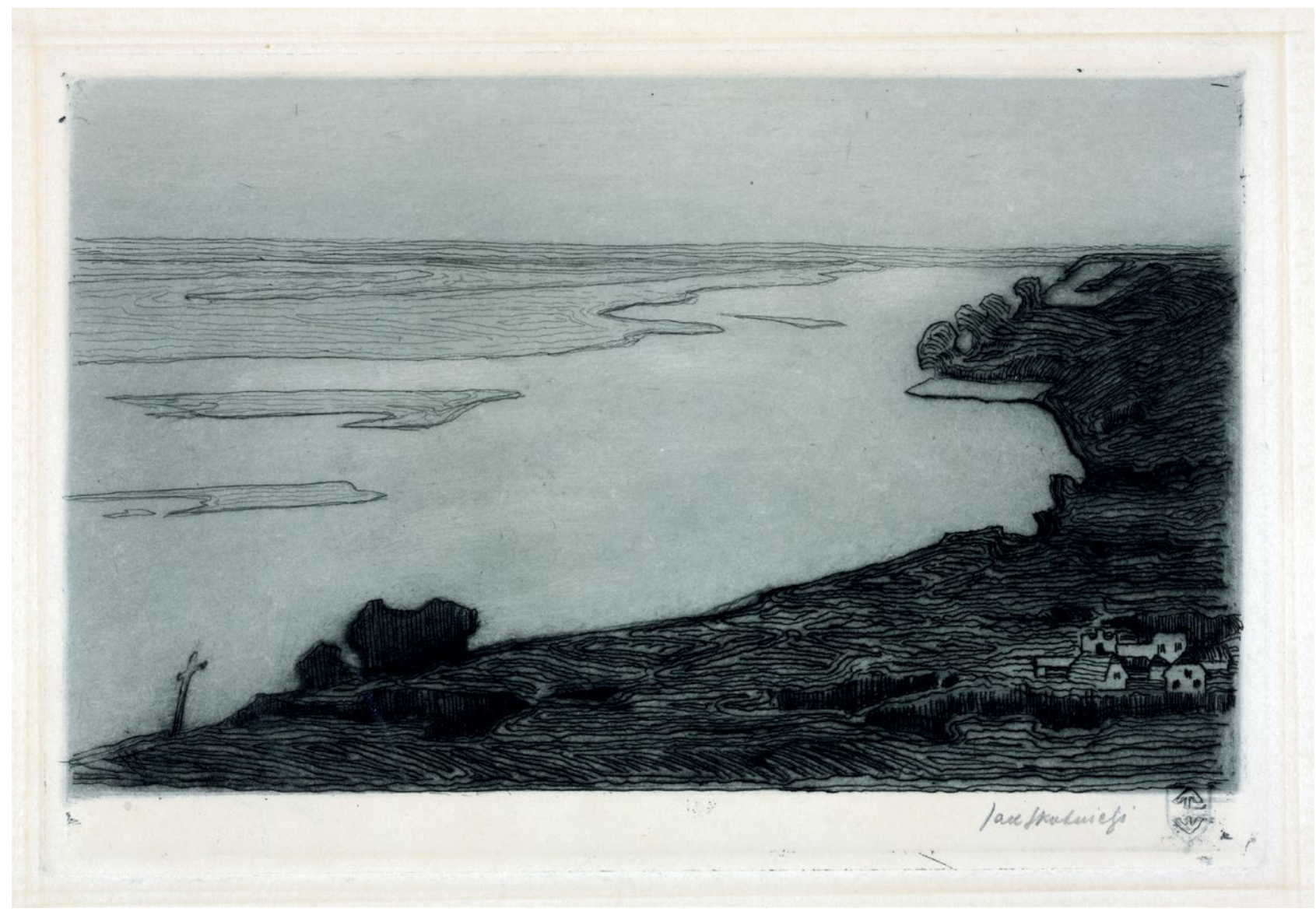

3. Jan Skotnicki, Wisła pod Kazimierzem, akwaforta, 1909-1913, Gabinet Rycin Biblioteki Uniwersyteckiej w Warszawie. Fot. BUW

Skotnickiego i Skoczylasa ${ }^{52}$. Podobnie wspomniana już Głowa starca zarówno tematem, jak i przestrzennością, rzeźbiarskością ujęcia przywołuje studia górali Skoczylasa ${ }^{53}$. Analogicznie motyw podwórza (Podwórzec klasztorny), czy spichlerza (Spichlerz w Kazimierzu) pojawia się w zbliżonych ujęciach kolejno u Stankiewiczówny i Rubczaka $^{54}$. Z Jabłczyńskim łączą Skotnickiego malarskie, rozmyte ujęcia architektury,

52 W. Skoczylas, Stary kościół w Rabce, 1914, akwaforta (GR BUW, Inw.Dep. 4726).

53 W. Skoczylas, Głowa starego górala, 1911, akwaforta (GR BUW, Inw.Dep. 4723), tenże, Pielgrzym, 1911, sucha igła (MNW, Gr.W.5829/1).

54 GR BUW, Inw.G.R. 2869; J. Skotnicki, Spichlerz w Kazimierzu, [1911], akwaforta (MNK, MNK-III-ryc.-8824); J. Rubczak, Stary spichlerz w Kazimierzu, 1909, akwaforta (GR BUW, Inw.Dep. 4712); Z. Stankiewicz, Podwórko kamienicy Fukiera, przed 1913, akwaforta (Muzeum Okręgowe im. Leona Wyczółkowskiego w Toruniu, Gr/3883 II S). którym dodatkowego wymiaru nadawało kolorowanie odbitek ${ }^{55}$.

Znaczący wpływ na twórczość polskich artystów urodzonych po 1850 r. miała sztuka japońska ${ }^{56}$. Stało się tak w dużej mierze za sprawą kolekcji i działalności Feliksa „Mangghi” Jasieńskiego. Jego starania na rzecz wypromowania sztuki japońskiej oraz grafiki artystycznej, podejmowane w Krakowie od 1902 r., były z pewnością znane Skotnickiemu ${ }^{57}$. Podobnie jak ich odbicie w pracach m.in. Wyczółkowskiego,

55 Np. kolorowana odbitka Wejścia do kościoła S. Germain l'Auxerrois (GR BUW, Inw.Dep.4886) i F. Jabłczyński, Wnętrze kościoła, 1911, ceratoryt kolorowany (MNW, Gr.Pol. 925).

56 A. Kluczewska-Wójcik, Japonia w kulturze i sztuce polskiej końca XIX wieku i początków XX wieku, Warszawa-Toruń 2016, s. 142.

57 Taż,, Feliks „Manggha” Jasieński i jego kolekcja w Muzeum Narodowym w Krakowie, Kraków 2014. 
Mehoffera, Józefa Pankiewicza, Wojciecha Weissa czy twórców z kręgu Zielonego Balonika, do którego sam należał. Analizując recepcję twórczości Japończyków w sztuce polskiej, Łukasz Kossowski wyróżnia dwie tendencje: pierwszą, powierzchowną, ograniczoną do dalekowschodniego kostiumu (japonerie) oraz drugą, dogłębną, widoczną w zmianie sposobu myślenia o budowaniu kompozycji, kadrowania, doborze perspektywy, asymetrii czy fragmentaryczności przedstawienia (japonisme) ${ }^{58}$. Skotnicki nie sięgał po japońskie motywy. Za to stosował ptasią perspektywę i grał pustką (Wisła pod Kazimierzem, il. 3), ograniczał głębię kompozycji i budował ją asymetrycznie (Burza, Kareta w podróży), stosował zbliżony, fragmentaryczny kadr ukazujący element wyabstrahowany z większej całości (Dąb, Jodła), umieszczał na pierwszym planie elementy układające się w swoistą kratownicę, zza której widoczne są plany dalsze (Słoneczniki) ${ }^{59}$. Stosował zatem zabiegi, w opinii Kossowskiego, dla japonizmu typowe.

W kontekście twórczości Skotnickiego nie można nie wspomnieć o wpływie kolekcji Henryka Grohmana. O jego działalności na rzecz odnowy sztuk graficznych, w którą angażował się Skotnicki, była już mowa. Niemniej jednak dostęp do zbiorów obrazujących renesans rytownictwa w Europie, obejmujących zarówno prace pionierów, jak i peintre-graveurów kolejnych pokoleń, musiał być dla artysty kluczowy. Choć kolekcję Grohmana, tworzoną od ok. 1905 r. zwykło się utożsamiać z Łodzią, to obecność zbiorów w Zakopanem przed I wojną światową potwierdzają wspomnienia Elżbiety Trenkler oraz publikacja Edwarda Chwalewika ${ }^{60}$.

58 Ł. Kossowski, Wielka fala. Inspiracje sztuka Japonii w polskim malarstwie i grafice, Warszawa-Toruń 2016, s. $49-60$.

59 GR BUW, Inw.G.R. 2874, Inw.Dep. 4884, Inw.G.R. 2840, Inw.Dep. 4761

60 E. Trenklerówna, dz. cyt., s. 5; E. Chwalewik, Zbiory polskie, t. 2, Warszawa-Kraków 1927, s. 534.
Kwestią otwartą pozostaje na razie odpowiedź na pytanie, czy to faktycznie Skotnicki, jak twierdzi Irena Kossowska, stymulował kolekcjonerską i mecenasowską działalność Grohmana ${ }^{61}$. Z całą pewnością można natomiast stwierdzić, że artysta wzorował się na pracach ze zbiorów teś$\mathrm{cia}^{62}$. Realizowana obecnie, przy okazji badań nad kolekcją Grohmana w GR BUW, rekonstrukcja jej inwentarza, pozwala na przybliżone określenie czasu i kolejności nabycia prac poszczególnych artystów ${ }^{63}$. A co za tym idzie na określenie, do których $\mathrm{z}$ nich Skotnicki mógł mieć dostęp, przebywając w Zakopanem. Jednym z najbardziej wyrazistych przykładów jest akwaforta Domki stare z cyklu lubelskiego wzorowana na Liverdun Jamesa McNeila Whistlera, która do kolekcji Grohmana trafiła w pierwszych latach jej tworzenia ${ }^{64}$. Jest to w obu przypadkach widok niskich zabudowań niewielkiego miasteczka z bielejącymi na ich tle sylwetkami zwierząt (kozy i krowy). W Akcie kobiecym w kapeluszu i pończochach pobrzmiewają echa femme fatale obecnej na wielu rycinach Féliciena Ropsa, których Grohman zgromadził ponad 20065. Głowa kobieca zwrócona w prawo (il. 4) swą miękką malarskością, zdaje się nawiązywać do prac Eugène'a Carrière'a także obecnych w kolekcji teścia artysty ${ }^{66}$. Ponadto $\mathrm{w}$ zbiorach lubującego się w technikach metalowych fabrykanta obecne były japonizujące prace Emila Orlika ${ }^{67}$, liczne przykłady grafiki

\footnotetext{
61 I. Kossowska, Świat..., dz. cyt., s. 16.

62 Taż, Narodziny..., dz. cyt., s. 118-199, 171.

63 U. Dragońska, Kolekcja Henryka Grohmana z Gabinetu Rycin Biblioteki Uniwersyteckiej w Warszawie - nowe perspektywy badawcze, w: Kolekcje. Kształtowanie, historia, dziedzictwo utracone, red. M. Mielnik, Gdańsk 2020, s. 68-71.

64 GR BUW, Inw.Dep. 4757; J.M. Whistler, Liverdun, 1858, akwaforta, GR BUW, Inw.Dep. 4434.

65 GR BUW, Inw.Dep. 4758.

66 GR BUW, Inw.G.R. 2873.

67 U. Dragońska, Dwóch Japończyków. Prace Emila Orlika
} 


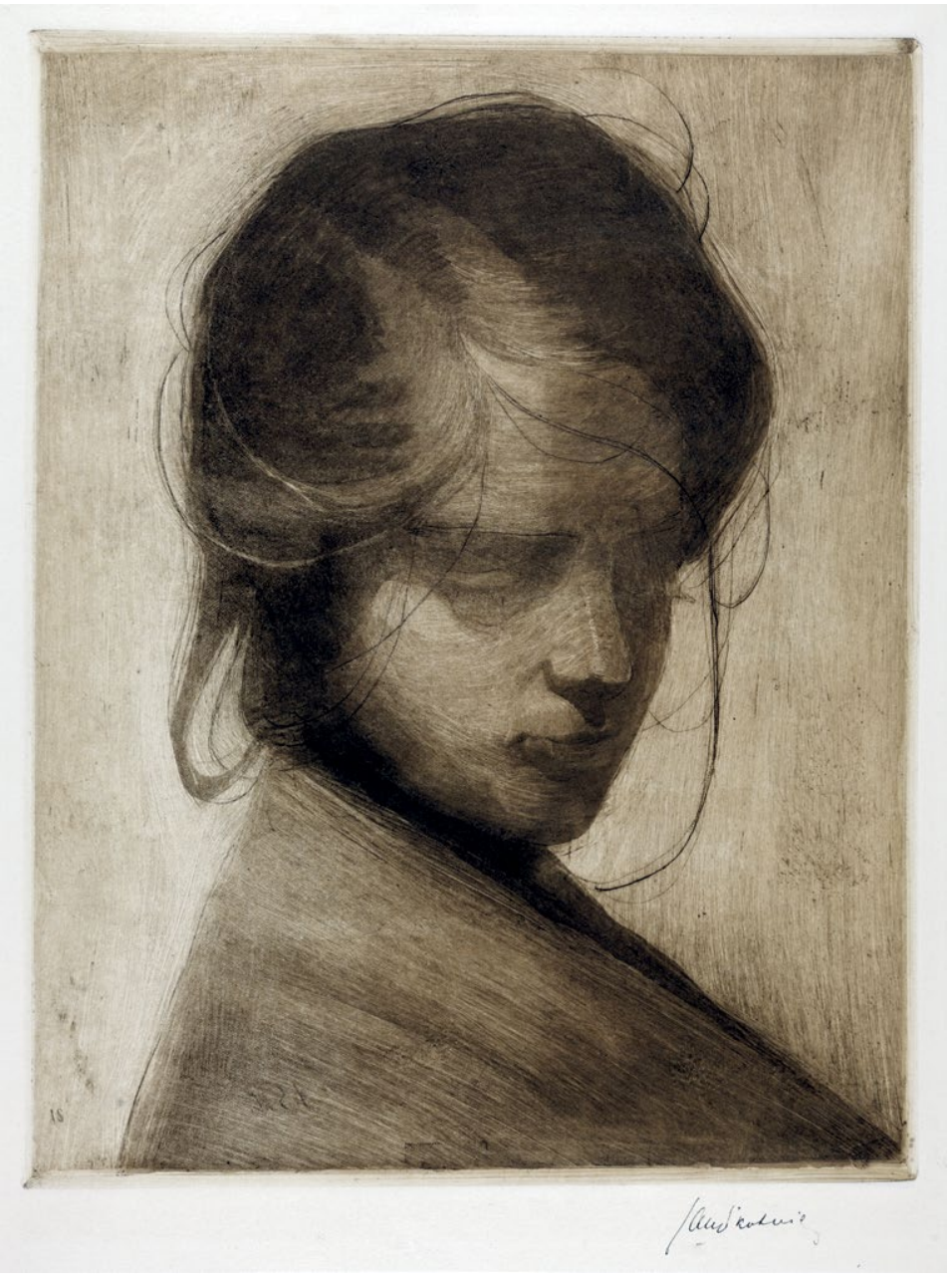

barwnej angielskiej i francuskiej, doskonałej klasy suche igły oraz akwaforty, które stanowiły punkt wyjścia dla początkującego w tym zakresie grafika.

Kwestie techniczne mocno zajmowały Skotnickiego, który nie ograniczał się do jednego wypracowanego sposobu trawienia czy rycia matrycy, a poszukiwał i eksperymentował. Drzeworytu nie uprawiał wcale, druk płaski był mu znany, ale nie poświęcił mu nadmiernej uwagi, skupił się na technikach metalowych. Stosował akwafortę, akwatintę i suchą igłę, samodzielnie lub w połączeniu. Kreskę urozmaicał przy pomocy ruletek. Znana jest także jedna praca wykonana w technice miękkiego werniksu

z kolekcji Henryka Grohmana, w: Jak we śnie! Emil Orlik w Japonii z kolekcji Petera Vossa-Andreae [katalog wystawy, Muzeum Sztuki i Techniki Japońskiej Manggha], red. A. Król, Kraków 2020, s. 33-42.
4. Jan Skotnicki, Głowa kobieca zwrócona w prawo, akwatinta, akwaforta, ruletka, 19091914 r., Gabinet Rycin Biblioteki Uniwersyteckiej w Warszawie. Fot. BUW

(Modelka w fotelu) $)^{68}$. Trawił stanowo, uzyskując w ten sposób gradacje od cienkich, delikatnych kresek po głębokie i mięsiste. Przy czym unikał szrafowania, ciemniejsze partie kompozycji pokrywając równoległym kreskowaniem (Przed kościołem, Wnętrze kościoła Mariackiego) ${ }^{69}$. Wybierając suchą igłę, potrafił wykorzystać zarówno jej miękką, pierzastą kreskę z wiórkiem, jak i delikatną i suchą, wiórka pozbawioną (Akt kobiecy $z$ tyłu). Stosował akwatintę o niezwykle drobnym, niemal niewidocznym ziarnie (Dworek, Jodła), być może lawował także kwasem bezpośrednio na matrycy. Twórczo podchodził do partii tła. Stosował papiery szmerglowe o różnej grubości dla zróżnicowania jego powierzchni (Domki stare). Wiele osiągał przy pomocy tinty, często pozostawiając na płycie warstwę niewytartej farby drukarskiej. Wzbogacał w ten sposób odbitki o światła i cienie, ścierając farbę całkowicie z powierzchni metalu w partiach jasnych lub pozostawiając jej grubą warstwę w miejscach zacienionych (Dama w fotelu ${ }^{70}$. Ślady szmaty, pędzla czy dłoni ścierających farbę z matrycy, także zdają się dopełniać kompozycję. Tak dalekie indywidualizowanie odbitki na etapie odbijania ociera się wręcz o zabiegi z pogranicza monotypii (Kobieta w kapeluszu ${ }^{71}$.

Choć sam twierdził, że to nie barwa, a linia decyduje o istocie pracy graficznej, Skotnicki chętnie sięgał po kolor ${ }^{72}$. Używał farby drukarskiej w różnych odcieniach, od głębokiej czerni, przez szarości, zielenie, granaty i brązy. Eksperymentował również $\mathrm{z}$ drukiem barwnym (Słoneczniki, Dworek). Kolor nakładał także bezpośrednio na odbitki farbami wodnymi, kryjącymi lub kredkami (Rzepicha, Wejście do kościoła

68 GR BUW, Inw.Dep. 4759.

69 GR BUW, Inw.Dep. 4767, Inw.G.R 2868.

70 GR BUW, Inw.Dep. 4894.

71 GR BUW, Inw.G.R. 2873.

72 J. Skotnicki, Kronika..., dz. cyt., s. 144. 


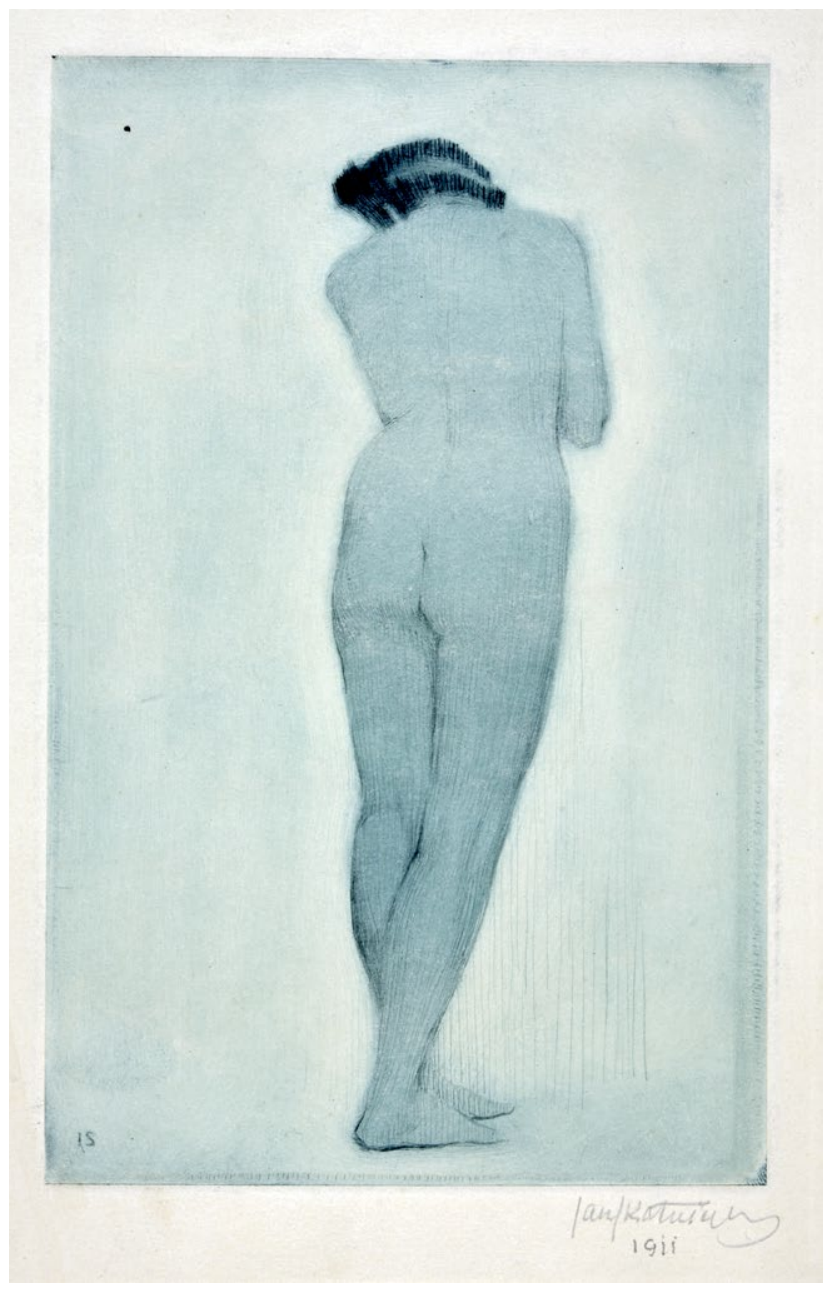

5. Jan Skotnicki, Akt kobiecy z tyłu, sucha igła w tonie niebieskim, 1911 r., Gabinet Rycin Biblioteki Uniwersyteckiej w Warszawie. Fot. BUW

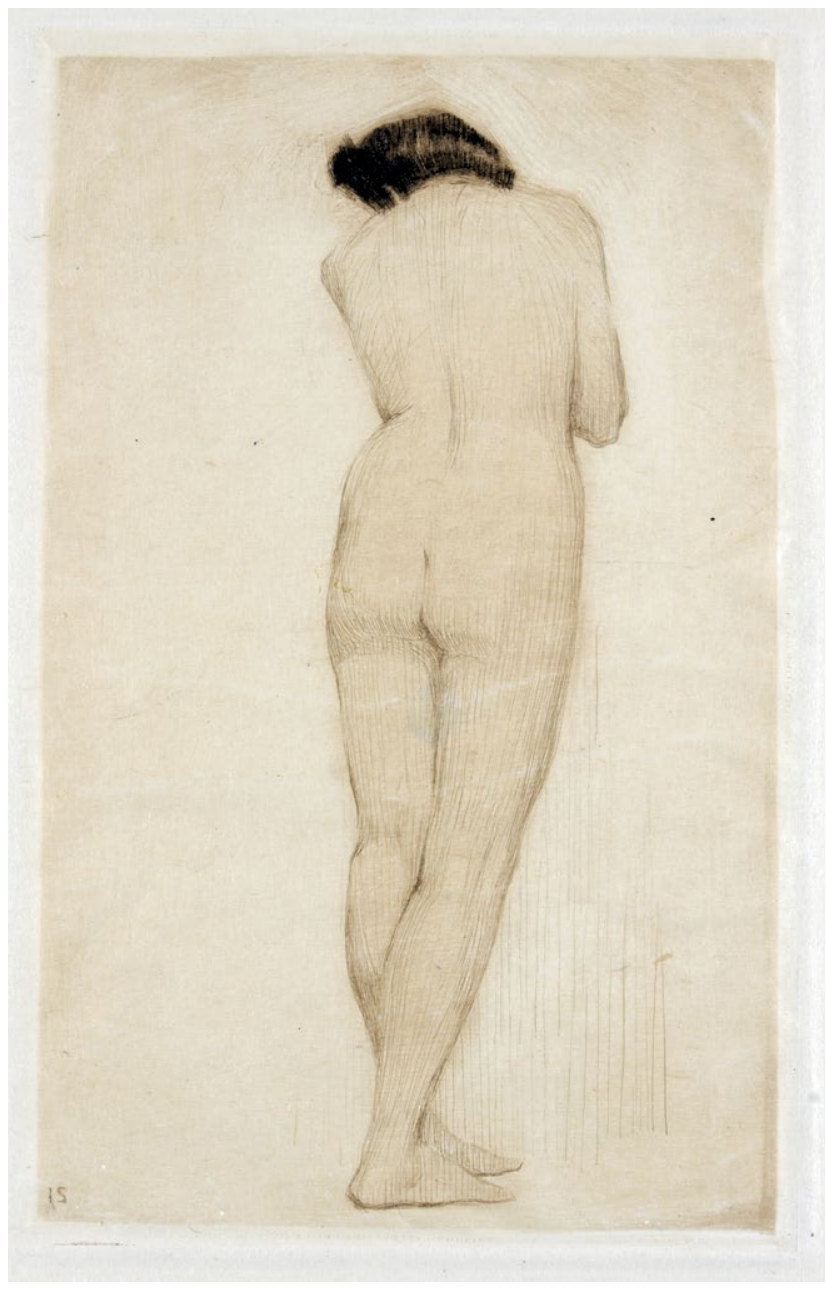

6. Jan Skotnicki, Akt kobiecy z tyłu, sucha igła w tonie brązowym, 1911 r., Gabinet Rycin Biblioteki Uniwersyteckiej w Warszawie. Fot. BUW
Saint Germain l'Auxerrois w Paryżu). Stosował zarówno rozmyte, nieregularne plamy barw, jak i mocne akcenty kolorystyczne. Kolorem zmieniał wydźwięk pracy. Dwie zachowane wersje kolorystyczne Aktu kobiecego z tyłu (il. 5-6) ukazują, jak barwą osiągał zupełnie odmienne efekty: odbitka brązowa ma w sobie ciepło i naturalność ludzkiego ciała, niebieska - tajemniczość i intymność wieczornej nagości, którą dodatkowo potęguje zastosowana tinta ciemniejsza na krawędziach płyty i starta dookoła kobiety, której ciało zdaje się w ten sposób emanować wewnętrznym blaskiem. Z kolei dwie różne kolorystycznie odbitki Jodły (oszczędna, z błękitem w partii nieba i intensywniejsza, czerwono-żółta) przypominają zabiegi Stanisławskiego, ukazującego ten sam wycinek natury lub miasta o różnych porach dnia i roku³. Skotnicki różnicował także używane papiery, uzależniając odcienie bieli i gramaturę od poszukiwanego efektu.

Kończąc rozważania na temat technicznych aspektów rycin Skotnickiego, warto zwrócić uwagę, że korzystał on także z dobrodziejstw fotografii i technik

\footnotetext{
73 Litografie Kościoła świętego Marka w Wenecji lub Topoli nad woda w różnych wersjach kolorystycznych. Wielość w jedności..., dz. cyt., s. 66-67, poz. 3-7.
} 
fotomechanicznych ${ }^{74}$. Fotografią fascynował się Mieczysław Karłowicz, jak również Elżbieta Trenkler ${ }^{75}$. Pytanie, czy w tym zakresie korzystał z zaplecza technicznego dostępnego w Zakopanem, czy może posiłkował się innymi ośrodkami, pozostaje otwarte ${ }^{76}$. Nie udało się ustalić, gdzie Skotnicki poznał tajniki technik metalowych. Nie ma wzmianek, by z grafiką zetknął się w trakcie swojej edukacji lub podróży. Mógł oczywiście doskonalić się w oparciu o dostępne podręczniki i prace z kolekcji teścia, mógł korzystać z lekcji kolegów, z którymi dzielił pracownię. Kwestie techniczne związane z jego pracami pozostawiają wątpliwości i wymagają pogłębienia badań, które utrudnia skąpy materiał porównawczy.

Epizod graficzny był w twórczości Jana Skotnickiego zjawiskiem krótkotrwałym, niemal w całości przypadającym na przymusowy pobyt artysty w Zakopanem. Wpisuje się on w częste wśród młodopolskich malarzy zainteresowanie sztukami graficznymi, uprawianymi zazwyczaj obok innych mediów, w oparciu o indywidualne poszukiwania bez instytucjonalnej edukacji warsztatowej. Tym bardziej należy podkreślić niezwykłą sprawność techniczną, którą artysta osiągnął na krótko po otwarciu zakopiańskiej pracowni. Twórczy eksperyment w zakresie łączonych technik metalowych, z zastosowaniem barwy i mocnym indywidualizowaniem odbitek, był tym, co w pracach Skotnickiego wybija się na plan pierwszy. Tematyka jego prac, niemająca

$74 \mathrm{Wg}$ fotografii wykonał w akwaforcie Autoportret (GR BUW, Inw.Dep. 4755). Kilka swoich prac zreprodukował zapewne w heliograwiurze: Akt kobiecy w kapeluszu i podwiazkach, Autoportret, Tour St Jacques w Paryżu (GR BUW, Inw.Dep. 4758, Inw.Dep. 4756, Inw.Dep. 4764).

75 Mieczysław Karłowicz..., dz. cyt., s. 608; T. Jabłońska, dz. cyt., s. 219.

76 O rozwoju fotografii w Zakopanem zob. T. Jabłońska, dz. cyt., s. 123-125, 219-221. zresztą nic wspólnego z tak inspirującym dla wielu tatrzańskim kurortem, była niejako pretekstem do poszukiwań warsztatowych. Stąd być może tak wiele autocytowań oraz nawiązań do sztuki młodopolskiej i grafiki europejskiej poznanej za sprawą Henryka Grohmana. W kontekście rozwoju polskich sztuk graficznych, twórczość Skotnickiego, pozostawiana często na marginesie, jest istotnym elementem obrazującym próby wypracowania autonomicznego języka wypowiedzi dla nowego, czy może zapomnianego, medium. A jego działalność, silnie związana z inicjatywami Grohmana, stanowi istotny wkład na rzecz popularyzacji grafiki warsztatowej i przywrócenia jej należytego miejsca w sztuce polskiej. Skotnicki nie był więc pionierem sztuk graficznych, ale z pewnością pretendował do miana ich propagatora. 


\section{STRESZCZENIE}

„PEJZAŻ GÓRSKI NIE ODPOWIADAŁ MI MALARSKO". ZAKOPIAŃSKI EPIZOD GRAFICZNY JANA SKOTNICKIEGO

W artykule omówiona została graficzna twórczość młodopolskiego malarza Jana Skotnickiego, przypadająca na lata 19091914. W 1908 r. artysta wraz z żoną Teodorą z Trenklerów wyjechali z Krakowa do Zakopanego. Pobyt artysty zbiegł się w czasie z intensywnym rozwojem kulturalnym kurortu. W miejscowe inicjatywy Skotnicki angażował się osobiście, przy finansowym wsparciu swego teścia, łódzkiego przemysłowca i kolekcjonera, Henryka Grohmana. Jednocześnie tutejszy krajobraz i popularna w owym czasie góralska sztuka ludowa, zupełnie artysty nie inspirowały, przez co niemal zarzucił malarstwo, a zainteresował się grafiką i kilimiarstwem. Polem nowych zainteresowań stała się otwarta staraniem Grohmana eksperymentalna pracownia wyposażona m.in. w prasy drukarskie. W kolejnych latach Skotnicki prezentował swoje ryciny na licznych wystawach, także tych towarzyszących organizowanym konkursom graficznym (1911, 1914), a po wyjeździe do Warszawy (1912) przyłączył się do Towarzystwa Przyjaciół Sztuk Graficznych. Skotnicki uprawiał techniki metalowe, bardzo szybko osiągając w nich wysoki poziom zauważony przez krytyków. Łączył akwafortę, akwatintę, suchą igłę i ruletkę, eksperymentował $\mathrm{z}$ drukiem barwnym i kolorował odbitki, mocno indywidualizował prace podczas ich odbijania, stosując tintę. Jego dorobek graficzny oszacowany zastał na ponad 50 kompozycji, przy czym w kolekcjach publicznych znajduje się ich obecnie przynajmniej 36. Są to pejzaże, widoki miasteczek i architektury, akty, studia postaci i zwierząt, w wielu przypadkach wzorowane na własnych szkicach i obrazach. Tematycznie i kompozycyjnie wykazują one wiele podobieństw do prac twórców

\section{SUMMARY}

"THE MOUNTAIN LANDSCAPE DID NOT SUIT ME ARTISTICALLY". A ZAKOPANE GRAPHIC EPISODE OF JAN SKOTNICKI

The article discusses the graphic output of Jan Skotnicki, a painter of Young Poland, which he created in the years 1909-1914. In 1908, the artist and his wife, Teodora née Trenkler, left Cracow for Zakopane. The artist's stay there coincided with the intensive cultural development of the resort.

Skotnicki was personally involved in local initiatives, with the financial support of his father-in-law, an industrialist and art collector from Łódź, Henryk Grohman. However, the local landscape and the highland folk art popular at that time did not suit him at all. As a result, he nearly gave up painting and became interested in prints and kilims. An experimental studio, opened thanks to Grohman's efforts, became Skotnicki's new field of interests. It was equipped with, among other things, printing presses. In the following years, Skotnicki presented his prints at numerous exhibitions, including those accompanying print competitions (in 1911 and 1914), and after moving to Warsaw (in 1912), he joined the Society of Friends of Graphic Arts. Skotnicki used metal techniques and quickly achieved a master level, which was noticed by critics. He combined etching, aquatints, drypoints and roulette, experimented with colour printing and coloured prints. He strongly individualised his works while creating prints by using tint. His graphic output was estimated at more than 50 compositions, with at least 36 currently in public collections. They include landscapes, views of towns and architecture, nudes, studies of figures and animals, which in many cases were modelled on his own sketches and paintings. In terms of themes and composition, they show many similarities to the works of Young Poland 
młodopolskich, zarówno z grona profesorów (J. Stanisławski), jak i rówieśników podejmujących próby graficzne (W. Skoczylas). W sposobie budowania kompozycji, kadrowania, asymetrii i fragmentaryczności przedstawień widoczne są wpływy sztuki japońskiej, stanowiącej ważne źródło inspiracji za sprawą kolekcji i działalności Feliksa „Mangghi” Jasieńskiego. Znacząca była również kolekcja Grohmana, za pośrednictwem której Skotnicki mógł poznać twórczość XIX-wiecznych odnowicieli sztuk graficznych, jak i artystów kolejnych pokoleń (J.M. Whistler, F. Rops, E. Carrière), co znalazło odbicie w jego rycinach.

Nieco zapomniana działalność Skotnickiego wpisuje się w ogólniejszą tendencję: zainteresowania młodopolskich artystów sztukami graficznymi i zaangażowania na rzecz ich popularyzacji na przełomie XIX i XX w. Jest przykładem poszukiwania własnego języka wypowiedzi w nowym medium, samodzielnie podejmowanego eksperymentu. Choć Skotnicki nie był pionierem sztuk graficznych na ziemiach polskich, to z pewnością stał się ich propagatorem.

\section{SŁOWA KLUCZOWE}

Jan Skotnicki, Zakopane, sztuki graficzne, grafika nowoczesna, akwaforta, sucha igła, grafika barwna, japonizm, Młoda Polska, kolekcjonerstwo, Henryk Grohman artists from the group of professors (J. Stanisławski) as well as peers undertaking graphic attempts (W. Skoczylas). The way of building the composition, framing, asymmetry and fragmentation of the representations reveal the influence of Japanese art, which was an important source of inspiration thanks to the collection and activity of Feliks "Manggha" Jasieński. Grohman's collection was also significant, as Skotnicki could learn from it about the works of 19th-century restorers of graphic arts, as well as about the artists of subsequent generations (J. M. Whistler, F. Rops, E. Carrière), which was reflected in his prints.

The somewhat forgotten activity of Skotnicki was part of a more general trend: the interest of Young Poland artists in graphic arts and their involvement in their popularisation at the turn of the 19th and zoth centuries. His output is an example of searching for one's own language of expression in a new medium, and an experiment he performed independently. Although Skotnicki was not a pioneer of graphic arts in Poland, he certainly became their promoter.

\section{KEYWORDS}

Jan Skotnicki, Zakopane, graphic arts, modern printing, etching, drypoint, colour printing, japonisme, Young Poland, art collecting, Henryk Grohman 


\section{BIBLIOGRAFIA}

\section{Opracowania}

III wystawa Grupy Artystów Polskich „Odłam” [katalog wystawy, IV-V 1910], Warszawa 1910.

Chwalewik Edward, Zbiory polskie, Warszawa-Kraków 1927.

Czarnocka Krystyna, Półtora wieku grafiki polskiej, Warszawa 1962.

Czyż Piotr P., Szkoła Łopieńskiego Towarzystwo Przyjaciół Sztuk Graficznych, czyli warszawscy akwaforciści pierwszych dwóch dekad XX wieku, w: Wielość w jedności. Techniki wklęsłodruku w Polsce po 1900 roku. Materiały z sesji naukowej 18-19 października 2012 roku, red. Barbara Chojnacka, Michał F. Woźniak, Bydgoszcz 2013, s. 63-80.

Dienstl Marian, Warszawskie Tow. artystów grafików, „Świat”, 1913, nr 17, s. 10-11.

Dragońska Urszula, Dwóch Japończyków. Prace Emila Orlika z kolekcji Henryka Grohmana, w: Jak we śnie! Emil Orlik w Japonii z kolekcji Petera Vossa-Andreae [katalog wystawy, Muzeum Sztuki i Techniki Japońskiej Manggha], red. Anna Król, Kraków 2020, s. 33-42.

Dragońska Urszula, Kolekcja Henryka Grohmana z Gabinetu Rycin Biblioteki Uniwersyteckiej w Warszawie - nowe perspektywy badawcze, w: Kolekcje. Kształtowanie, historia, dziedzictwo utracone, red. Magdalena Mielnik, Gdańsk 2020, s. 61-75.

Dział grafiki na wystawie Odłamu w TZSP, „Kurier Warszawski”, 1910, nr 143 (wydanie wieczorne), s. 6.

Estreicher Karol, Środowisko artystyczne Zakopanego w okresie Młodej Polski (1900-1914), w: Sztuka około 1900. Materiały sesji Stowarzyszenia Historyków Sztuki, Kraków, grudzień 1967, Warszaw 1969, s. 129-140.
Grońska Maria, Władysław Skoczylas, Wrocław 1966.

Grońska Maria, Rysunki artystów polskich i obcych w Polsce działajacych od XVII do XX wieku. Katalog wybranych zbiorów Biblioteki Narodowej do 1975 roku, Warszawa 1991.

Jabłońska Teresa, Sztuki piękne pod Tatrami, Zakopane 2015.

Jan Skotnicki - malarz i jego warsztat [katalog wystawy, Muzeum im. Jerzego DuninBorkowskiego w Krośniewicach, VIIIX 1998], oprac. i tekst Piotr Stasiak, Krośniewice 1998.

Jubileuszowa wystawa prac Jana Skotnickiego [katalog wystawy, Centralne Biuro Wystaw Artystycznych, VI-VIII 1957], Warszawa 1957.

Kacprzak Dariusz, Kolekcje Ziemi Obiecanej. Zbiory artystyczne łódzkiej burżuazji wielkoprzemysłowej w latach 18801939, Warszawa 2015.

Katalog wystawy podhalańskiej, [katalog wystawy], Lwów 1911.

Kleczyński Jan, Z wystawy „Odłamu”. Szkice sylwetek, „Sfinks. Czasopismo literacko-artystyczne i naukowe", r. 3, 1910, t. 10, s. 313 .

Kluczewska-Wójcik Agnieszka, Feliks „Manggha” Jasieński i jego kolekcja w Muzeum Narodowym w Krakowie, Kraków 2014.

Kluczewska-Wójcik Agnieszka, Japonia w kulturze i sztuce polskiej końca XIX wieku i początków XX wieku, Warszawa-Toruń 2016.

Konarski Stanisław, Skotnicki Jan, w: Polski słownik biograficzny, t. 38, Warszawa 1997-1998, s. 302-305.

Koniec wieku. Sztuka polskiego modernizmu 1890-1914 [katalog wystawy, Muzeum Narodowe w Warszawie, 15 XI 1996 26 I 1997, Muzeum Narodowe w Krakowie, 15 III - 15 V 1997], red. Elżbieta Charazińska, Łukasz Kossowski, Warszawa 1996. 
Kossowska Irena, Poetyka czerni i bieli w sztuce polskiego modernizmu. Grafika i rysunek, w: Koniec wieku. Sztuka polskiego modernizmu 18901914 [katalog wystawy, Muzeum Narodowe w Warszawie, 15 XI 1996 26 I 1997, Muzeum Narodowe w Krakowie, 15 III - 15 V 1997], red. Elżbieta Charazińska, Łukasz Kossowski, Warszawa 1996, s. 65-74.

Kossowska Irena, Narodziny polskiej grafiki artystycznej 1897-1914, Kraków 2000.

Kossowska Irena, Świat odrealniony. Polska grafika artystyczna (1897-1917), w: W stulecie Bazaru PolskiegoHenryk Grohman i grafika Młodej Polski [katalog wystawy, Miejska Galeria Sztuki im. Władysława hr. Zamoyskiego w Zakopanem], Kraków 2011, s. 16-34.

Kossowski Łukasz, Wielka fala. Inspiracje sztuką Japonii w polskim malarstwie i grafice, Warszawa-Toruń 2016.

Mieczysław Karłowicz w listach i wspomnieniach, oprac. Henryk Anders, Kraków 1960.

Moździerz Zbigniew, O powstaniu Bazaru Polskiego w Zakopanem, w: W stulecie Bazaru Polskiego - Henryk Grohman i grafika Młodej Polski [katalog wystawy, Miejska Galeria Sztuki im. Władysława hr. Zamoyskiego w Zakopanem], Kraków 2011], s. 4-11.

Nowoczesna grafika polska, [katalog wystawy], Antykwariat Polski w Warszawie Hieronima Wildera i S-ki, Warszawa 1913.

Pamiątka z wystawy graficznej i konkursu IIgo imienia Henryka Grohmana [katalog wystawy, II 1914], Warszawa 1914.

Piątkowski Henryk, Wystawa obrazów J. Skotnickiego, „Tygodnik Ilustrowany", 1913, nr 45, s. 885-886.

Polskie życie artystyczne w latach 1890-1914, red. Aleksander Wojciechowski, Wrocław-Warszawa-Kraków 1967.
Rohrschneider Christine, Skotnicki Jan, w: Allgemeines Künstlerlexikon. Die Bildenden Künstler aller Zeiten und Völker, Bd. 104, Berlin-Boston 2019, S. 201-202.

Rudzińska Wanda M., Henryk Grohman mecenas i kolekcjoner, w: Mecenas, kolekcjoner, odbiorca. Materiały Sesji Stowarzyszenia Historyków Sztuki, Katowice, listopad 1981, red. Elżbieta Karwowska, Anna Marczak-Krupa, Warszawa 1984, s. 179-195.

Rudzińska Wanda M., Nowoczesna grafika polska w świetle warszawskiej „Wystawy Graficznej” z 1914 r., w: Przed wielkim jutrem. Sztuka 19051918. Materiały Sesji Stowarzyszenia Historyków Sztuki, Warszawa, październik 1990, red. Teresa Hrankowska, Warszawa 1993, s. 325-339.

Rudzińska Wanda M., Henryk Grohman i jego kolekcja grafiki europejskiej i polskiej przełomu XIX i XX wieku, w: Polskie kolekcjonerstwo grafiki. Ludzie i instytucje, red. Ewa Frąckowiak, Anna Grochala, Warszawa 2008, s. 128-137. Rudzińska Wanda M., Wystawa graficzna w Bazarze Polskim w Zakopanem i Henryk Grohman - przemysłowiec, mecenas sztuki, kolekcjoner, w: W stulecie Bazaru Polskiego - Henryk Grohman i grafika Młodej Polski [katalog wystawy, Miejska Galeria Sztuki im. Władysława hr. Zamoyskiego w Zakopanem], Kraków 2011, s. 36-42.

Sitkowska Maryla, Władysław Skoczylas (1883-1934), Warszawa 2015.

Skotnicki Jan, Kronika. Wystawa graficzna w Zakopanem, „Sztuka. Miesięcznik ilustrowany poświęcony sztuce i kulturze", 1911, z. 1, s. 144-147.

Skotnicki Jan, Przy sztalugach i przy biurku, t. 1-2, [ok. 1950] Wojewódzka Biblioteka Publiczna w Łodzi, Rps XIV/1-2. 
Skotnicki Jan, Przy sztalugach i przy biurku. Wspomnienia i rozmyślania 1876-1950, t. 1-2 [ok. 1950], Biblioteka Narodowa, Rps 6395-6396 IV.

Skotnicki Jan, Przy sztalugach i przy biurku, Warszawa 1957.

Stasiak Piotr, O malarstwie Jana Skotnickiego, w: Jan Skotnicki - malarz i jego warsztat [katalog wystawy, Muzeum im. Jerzego Dunin-Borkowskiego w Krośniewicach, VII-IX 1998], oprac. i tekst Piotr Stasiak, Krośniewice 1998, nlb.

Sznapik Adrianna Dominika, Tatrzańska Arkadia. Zakopane jako ośrodek artystyczno-intelektualny od około 1880 do 1914 roku, Warszawa 2009.

Trenklerówna Elżbieta, Ze wspomnień o Mieczysławie Karłowiczu, „Ruch Muzyczny", 1968, nr 8, s. 3-6.

W stulecie Bazaru Polskiego - Henryk Grohman i grafika Młodej Polski [katalog wystawy, Miejska Galeria Sztuki im. Władysława hr. Zamoyskiego w Zakopanem, autorki scenariusza Irena Kossowska, Wanda M. Rudzińska], Kraków 2011.

Wankie Władysław, Nasza grafika współczesna, „Świat”, 1914, nr 5, s. 4-6.

Wielość w jedności. Techniki wklęsłodruku w Polsce po 1900 [katalog wystawy,
Muzeum Okręgowe im. Leona Wyczółkowskiego w Bydgoszczy, 23 IX - 2 XII 2012], oprac. i red. naukowa Barbara Chojnacka, Bydgoszcz 2012.

Wiercińska Janina, Katalog prac wystawionych w Towarzystwie Zachęty Sztuk Pięknych w Warszawie w latach 18601914, Wrocław-Warszawa-Kraków 1969.

Wightman Alistair, Karłowicz, Młoda Polska i muzyczny fin de siècle, tłum. Ewa Gabryś, Kraków 1996.

Woźniakowski Jacek, O wystawach „Sztuki Podhalańskiej”, „Roczniki Humanistyczne", t. 34, 1986, z. 2, s. 525-530.

Woźniakowski Jacek, Dobrańsze niż indziej towarzystwo. Życie artystyczne w Zakopanem do roku 1939, w:Zakopane. Czterysta lat dziejów, red. Renata Dutkowa, t. 2, Kraków 1991, s. 189-235.

Ze zbiorów Henryka Grohmana. Grafika i rzemiosło artystyczne [katalog wystawy, Muzeum Sztuki w Łodzi, 24 I - 13 III 1998, komisarze wystawy i autorzy koncepcji katalogu Dorota Berbelska, Dariusz Kacprzak], red. Elżbieta Fuchs, Łódź 1997. 